\title{
Effects of heavy metals on benthic macroinvertebrate communities in high mountain streams
}

\author{
Xiaodong $\mathrm{Qu}^{1}$, Naicheng $\mathrm{Wu}^{2}$, Tao Tang ${ }^{2}$, Qinghua Cai ${ }^{2}$ and Young-Seuk Park ${ }^{1 *}$ \\ ${ }^{1}$ Department of Biology and The Korea Institute of Ornithology, Kyung Hee University, Dongdaemun, Seoul 130-701, \\ Republic of Korea \\ ${ }^{2}$ State Key Laboratory of Freshwater Ecology and Biotechnology, Institute of Hydrobiology, Chinese Academy of Sciences, \\ Wuhan 430072, P.R. China
}

Received 13 April 2010; Accepted 16 August 2010

\begin{abstract}
We characterized the responses of benthic macroinvertebrates to heavy metals released from mines in high mountain streams of the Gangqu River in the Shangrila Gorge, China. Benthic macroinvertebrates were collected with a kick-net at 32 sampling sites. In addition, 25 environmental variables including heavy metal concentrations were measured at each sampling site. Although the concentrations of heavy metals were not seriously high, their effects were reflected in the changes of community composition of benthic macroinvertebrates. Total abundance and species richness decreased with increasing heavy metal concentrations. Species richness of Plecoptera and Trichoptera, Margalef richness index, and percentage of scrapers in functional feeding groups were negatively correlated with heavy metal concentrations. A high variation was observed in the response of different taxa to heavy metals. Heavy metals mainly affected the sensitive taxa of Plecoptera, Ephemeroptera, and Trichoptera. However, some tolerant taxa were observed in Trichoptera (such as Hydropsyche sp.) and Dugesia sp. Cluster analysis and a non-metric multidimensional scaling analysis were applied to characterize specific macroinvertebrate taxa composition. The analyses revealed the effects of different environmental factors such as geographical, hydromorphological, physical, and chemical factors including heavy metals on the distribution of benthic macroinvertebrates in high mountain streams. Although the effects were compounded with different factors such as altitude, temperature, stream width, turbidity, and heavy metals, the influence of heavy metals on benthic macroinvertebrate communities was clearly identified (decreased species richness, changes in species composition). Even though the contamination of heavy metals was low in the sampling area, the consequences were clear, indicating that longterm exposure to heavy metals could seriously impact aquatic communities in high mountain streams.
\end{abstract}

Key words: Benthos / China / high mountain streams / mines / pollution / invertebrates

\section{Introduction}

Heavy metal pollution is of widespread concern for ecological management of streams and rivers. Drainage water from both active and abandoned mines may be the major source of heavy metal contamination in mountain streams. Most field studies of the effects of heavy metals on aquatic organisms, including benthic macroinvertebrates, have been conducted in mountain streams of Europe and the Americas, e.g., in Sweden (Malmqvist and Hoffsten, 1999), Ireland (Gray and Delaney, 2008), Spain (Solà and Prat, 2006), Colorado (Clements, 1994), Idaho (Maret et al., 2003), Virginia (Cherry et al., 2001), and Bolivia (van Damme et al., 2008). In China, the effects of heavy

\footnotetext{
*Corresponding author: parkys@khu.ac. kr
}

metal pollution are underestimated due to limited research in high mountain areas (Jiang et al., 2008). There is, however, a pressing need for ecological risk assessments to protect and manage aquatic ecosystems in these areas.

Biomonitoring approaches have been used to assess the effects of contaminants on aquatic organisms since the early 1900s (Carpenter, 1924). Most of these researches have focused on responses of benthic macroinvertebrates (Carlisle and Clements, 2003). Benthic macroinvertebrate assemblages contain species with various sensitivities to contaminants and have been widely used to evaluate the ecological impacts of metal contamination in streams (Maret et al., 2003). Metal contamination can reduce benthic macroinvertebrate species richness, as well as density, growth and production (Maret et al., 2003; Gray and Delaney, 2008). Heavy metals can be accumulated 


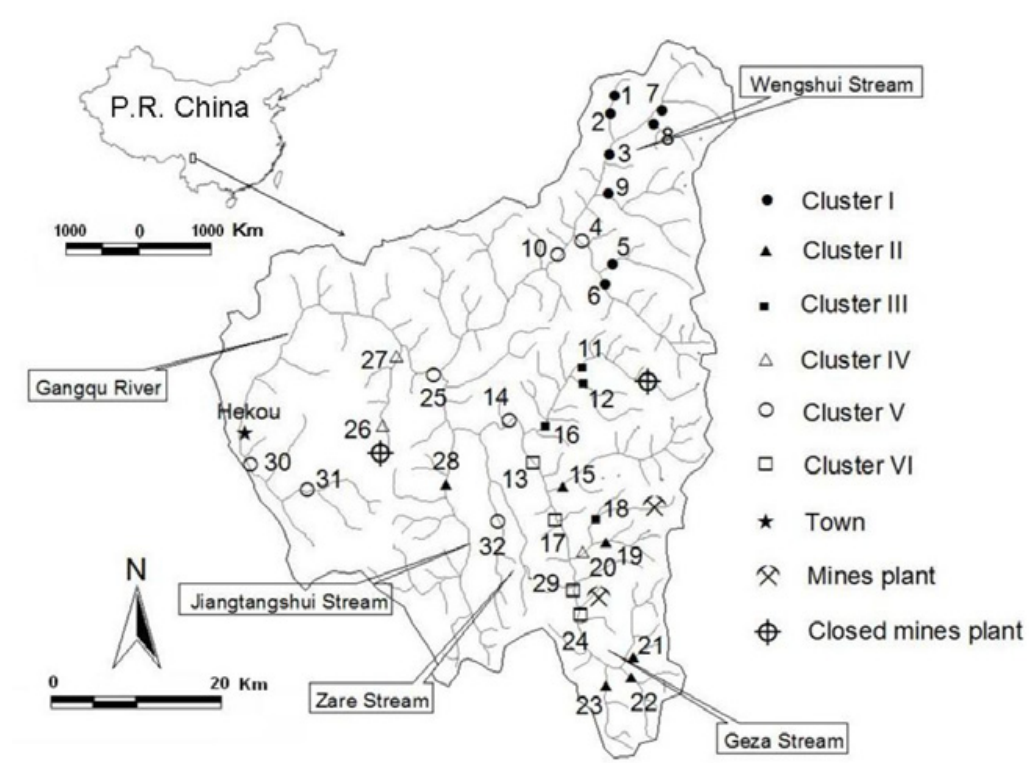

Fig. 1. Sampling sites in the Gangqu River of Shangrila Gorge. The different symbols indicate different clusters of the sampling sites based on the cluster analysis (see Fig. 3).

in the gut and tissues of individuals (Solà and Prat, 2006), which can affect predator-prey interactions in macroinvertebrate (Clements, 1999) and even fish communities (Freund and Petty, 2007) through the food web.

The effects of heavy metals on macroinvertebrates are highly variable among taxa (Kiffney and Clements, 1996). Heavy metals may also have an effect on ecosystem function. Clements et al. (2000) recorded a change in functional feeding groups (FFG) of benthic macroinvertebrates with lower abundances of scrapers, shredders, collectors, and predators at stations with medium- and high-concentrations of heavy metals, compared with reference stations. Predators may be the most sensitive species to heavy metals, especially $\mathrm{Zn}$ (Carlisle and Clements, 1999; Watanabe et al., 2008). Correspondingly, a shift in community composition from sensitive to tolerant taxa can occur when aquatic ecosystems are contaminated by heavy metals, thereby affecting the whole food web (Beltman et al., 1999). These general patterns are consistent across many regions in lowland areas (Freund and Petty, 2007). Benthic macroinvertebrates, however, were found to be more sensitive to heavy metals at higher elevations (Clements et al., 2000).

The generality of these responses in metal-polluted streams from high mountain areas has not been extensively examined in China. In this study we aimed at characterizing the effects of low contaminations of heavy metals released from both active and abandoned mines on benthic macroinvertebrate communities. The study area is in the Gangqu River of the Shangrila Gorge at SouthWest of China. Human population density is low in this area, so the exploitation of minerals is the main human disturbance (Wu et al., 2007). The Shangrila Gorge has been defined as a national reserve park of China, and it is also located in the world natural heritage "Three Parallel
Rivers", formed basically by three large rivers of Asia: the Yangtze, Mekong and Salween. This area is an epicentre of Chinese biodiversity, and also one of the richest temperate regions of the world in terms of biodiversity (UNESCO, 2003). We characterized the effects of low concentrations of heavy metals released from both active and abandoned mines on benthic macroinvertebrate communities in high altitude mountain streams of the Gangqu River system, an important upstream tributary of the Yangtze River.

\section{Materials and methods}

\section{Study area}

Sampling sites were located in the Gangqu River of the Shangrila Gorge $\left(\mathrm{N} 28^{\circ} 07^{\prime} \sim 28^{\circ} 36^{\prime}, \mathrm{E}^{\circ} 9^{\circ} 22^{\prime} \sim 100^{\circ} 06^{\prime}\right)$ in China (Fig. 1). The Gangqu River is a tributary of the upper reaches of the Jingsha River which is one of main tributaries of the Yangtze River. The Gangqu River has a length of $98 \mathrm{~km}$ with catchment area of $2644 \mathrm{~km}^{2}$. Its average discharge is $43.7 \mathrm{~m}^{3} \cdot \mathrm{s}^{-1}$, with a maximum of $122 \mathrm{~m}^{3} . \mathrm{s}^{-1}$ and a minimum of $11.2 \mathrm{~m}^{3} . \mathrm{s}^{-1}$. It has an average gradient of $15 \%$ and a natural fall of more than $2000 \mathrm{~m}$. There are two main tributaries of the Gangqu River: the Wengshui Stream located in the northern part of the watershed, and Geza Stream located in the southern region. The study area is highly canopied and undisturbed by human activity at high altitude areas (from 2150 to $3771 \mathrm{~m})$.

Four mines (two active and two abandoned for $\mathrm{Pb}$ and $\mathrm{Zn}$ ) were identified in the study area. The active mines are located at the watershed of the Geza Stream. The two abandoned mines - formerly active in $\mathrm{Pb}$ and $\mathrm{Zn}$ 
mining-are at the tributaries of the Jiangtanghui and Geza streams, respectively (Fig. 1). Additionally, there were local reports of several abandoned mines in the northern part of downstream areas, although their precise numbers and locations were not presently determined because of limited information and difficulty to access the areas.

\section{Sample collection}

Benthic macroinvertebrates were collected at 32 sampling sites using a kick-net $(1 \mathrm{~m} \times 1 \mathrm{~m}, 500 \mu \mathrm{m}$ mesh) in May 2005 before the monsoon season. Three replicates were taken at each sampling site with two samples in riffles and one sample in an area with relatively low velocity. Each sample was put into a separate one liter jar and fixed with $4 \%$ formaldehyde. Considering the mines mainly located at the upstream area, 26 sites were sampled from the first-to-third order streams in the study area and the remaining six sites were from fourth and fifth order streams. Ten sampling sites were in the Wongshui Stream, 15 were in the Geza Stream, with the remainder located in the main portion of the stream and small tributaries (Fig. 1).

The organisms of each sample were preserved in $70 \%$ alcohol. In the lab, we rinsed the samples through a sieve (500 $\mu \mathrm{m}$ mesh). The retained invertebrates were sorted and identified generally to genus level. While Chironomidae and Hirudinea were identified to family level, the Oligochaeta, Nematoda and Hydracarina were not identified due to the relatively low numbers of individuals.

\section{Environmental factors}

At each sampling site, 25 physical, chemical, hydrological, and geographical factors were measured (Table 1). Dissolved oxygen (DO), water temperature, total dissolved solids (TDS), $\mathrm{pH}$, nitrate $\left(\mathrm{NO}_{3}-\mathrm{N}\right)$, calcium $(\mathrm{Ca})$, chloride $(\mathrm{Cl})$, fluoride $(\mathrm{F})$, ammonia $\left(\mathrm{NH}_{3}-\mathrm{N}\right)$, and turbidity were measured in situ with a water quality monitoring system (Horiba, W-23XD). Altitude was measured using a GPS receiver (Magellan 315). Current velocity was measured with an OTT $^{\circledR}$ electromagnetic current meter. Stream width and water depth were measured with a ruler. The other environmental factors were measured in the lab. The concentrations of five heavy metals $(\mathrm{Cu}, \mathrm{Pb}, \mathrm{Zn}, \mathrm{Cd}$, and $\mathrm{Ni})$ were determined by a standard atomic absorption spectrophotometric method (APHA, 1992) using a spectrophotometer (Hitachi, Z-8000). $\mathrm{SiO}_{2}$ was measured using the molybdosilicate method (APHA, 1992). Total phosphorus (TP), total nitrogen $(\mathrm{TN})$, chemical oxygen demand $\left(\mathrm{COD}_{\mathrm{Mn}}\right)$, and phosphate $\left(\mathrm{PO}_{4}-\mathrm{P}\right)$ were measured according to the Chinese Standard Methods (Huang, 1999), and nitrite $\left(\mathrm{NO}_{2}-\mathrm{N}\right)$ and Chlorophyll- $a$ (Chl- $a$ ) were determined by using UV spectrophotometric method according to the Standard Methods for Water and Wastewater Monitoring
Table 1. Characteristics of environmental factors measured at the sampling sites.

\begin{tabular}{|c|c|c|c|c|}
\hline $\begin{array}{l}\text { Environmental } \\
\text { factors }\end{array}$ & Unit & Mean & SD & Range \\
\hline Width & $\mathrm{m}$ & 8.41 & 5.59 & $1.00-30.00$ \\
\hline Depth & $\mathrm{cm}$ & 26.30 & 12.17 & $4.33-60.00$ \\
\hline Velocity & $\mathrm{m} \cdot \mathrm{s}^{-1}$ & 0.79 & 0.28 & $0.32-1.79$ \\
\hline Altitude & M & 3144.34 & 392.54 & $2150-3771$ \\
\hline Temperature & ${ }^{\circ} \mathrm{C}$ & 9.05 & 3.33 & $4.55-18.99$ \\
\hline $\mathrm{pH}$ & & 7.91 & 0.26 & $7.30-8.50$ \\
\hline DO & mg. $\mathrm{L}^{-1}$ & 11.72 & 1.54 & $8.38-14.16$ \\
\hline Turbidity & NTU & 22.83 & 29.05 & $3.10-120.00$ \\
\hline TDS & mg. $\mathrm{L}^{-1}$ & 90.31 & 30.95 & $40.0-160.00$ \\
\hline $\mathrm{Cl}$ & mg. $\mathrm{L}^{-1}$ & 1.33 & 1.16 & $0.07-4.67$ \\
\hline $\mathrm{F}$ & mg. $\mathrm{L}^{-1}$ & 0.11 & 0.15 & $0.004-0.623$ \\
\hline $\mathrm{Ca}$ & mg. $\mathrm{L}^{-1}$ & 71.79 & 127.80 & $4.48-621.00$ \\
\hline $\mathrm{SiO}_{2}$ & mg. $\mathrm{L}^{-1}$ & 4.95 & 0.96 & $3.62-8.15$ \\
\hline $\mathrm{Cd}$ & $\mu \mathrm{g} . \mathrm{L}^{-1}$ & 0.35 & 0.13 & $0.12-0.61$ \\
\hline $\mathrm{Cu}$ & $\mu \mathrm{g} . \mathrm{L}^{-1}$ & 5.87 & 10.29 & $1.10-57.70$ \\
\hline $\mathrm{Pb}$ & $\mu \mathrm{g} . \mathrm{L}^{-1}$ & 12.05 & 14.80 & $3.60-89.10$ \\
\hline $\mathrm{Zn}$ & $\mu \mathrm{g} . \mathrm{L}^{-1}$ & 13.12 & 23.69 & $0.00-97.30$ \\
\hline $\mathrm{Ni}$ & $\mu \mathrm{g} . \mathrm{L}^{-1}$ & 3.25 & 0.89 & $1.90-5.20$ \\
\hline $\mathrm{PO}_{4}-\mathrm{P}$ & mg. $\mathrm{L}^{-1}$ & 0.006 & 0.0064 & $0.0003-0.0202$ \\
\hline $\mathrm{TP}$ & mg. $\mathrm{L}^{-1}$ & 0.009 & 0.0050 & $0.0012-0.0214$ \\
\hline $\mathrm{NO} 3-\mathrm{N}$ & mg. $\mathrm{L}^{-1}$ & 0.299 & 0.0828 & $0.133-0.507$ \\
\hline TN & mg. $\mathrm{L}^{-1}$ & 1.05 & 0.17 & $0.678-1.358$ \\
\hline $\mathrm{NH}_{3}-\mathrm{N}$ & mg. $\mathrm{L}^{-1}$ & 0.10 & 0.06 & $0.019-0.233$ \\
\hline $\mathrm{COD}_{\mathrm{Mn}}$ & mg. $\mathrm{L}^{-1}$ & 1.19 & 0.54 & $0.60-2.85$ \\
\hline Chl- $a$ Mn & mg. $L^{-1}$ & 45.71 & 44.24 & $2.73-174.71$ \\
\hline
\end{tabular}

and Analysis (Chinese Environmental Protection Chief Bureau, 2002).

\section{Data analyses}

We examined several commonly used metrics of community composition such as total abundance, total species richness, and species richness of selected taxa (Ephemeroptera, Plecoptera, and Trichoptera; EPT) based on the assumption that they are the most sensitive insect taxa to heavy metal pollution. Community indices such as Shannon diversity index (Shannon, 1948), Pielou's evenness (Pielou, 1966), and Margalef richness index (Clifford and Stephenson, 1975) were calculated at each sampling site. The following functional feeding groups (FFGs) were defined for each sampling sites: collector-filterers, collector-gatherers, predators, shredders, and scrapers (see Merritt and Cummins, 1996).

Differences of benthic macroinvertebrate communities in relation to environmental variables were analyzed using multivariate statistical analyses: hierarchical cluster analysis and non-metric multidimensional scaling (NMDS). Cluster analysis was used to classify the sampling sites based on the species abundance of macroinvertebrate communities using Ward's linkage method with Euclidean distance measure using PC-ORD software (McCune and Mefford, 1999). Differences among clusters were tested 

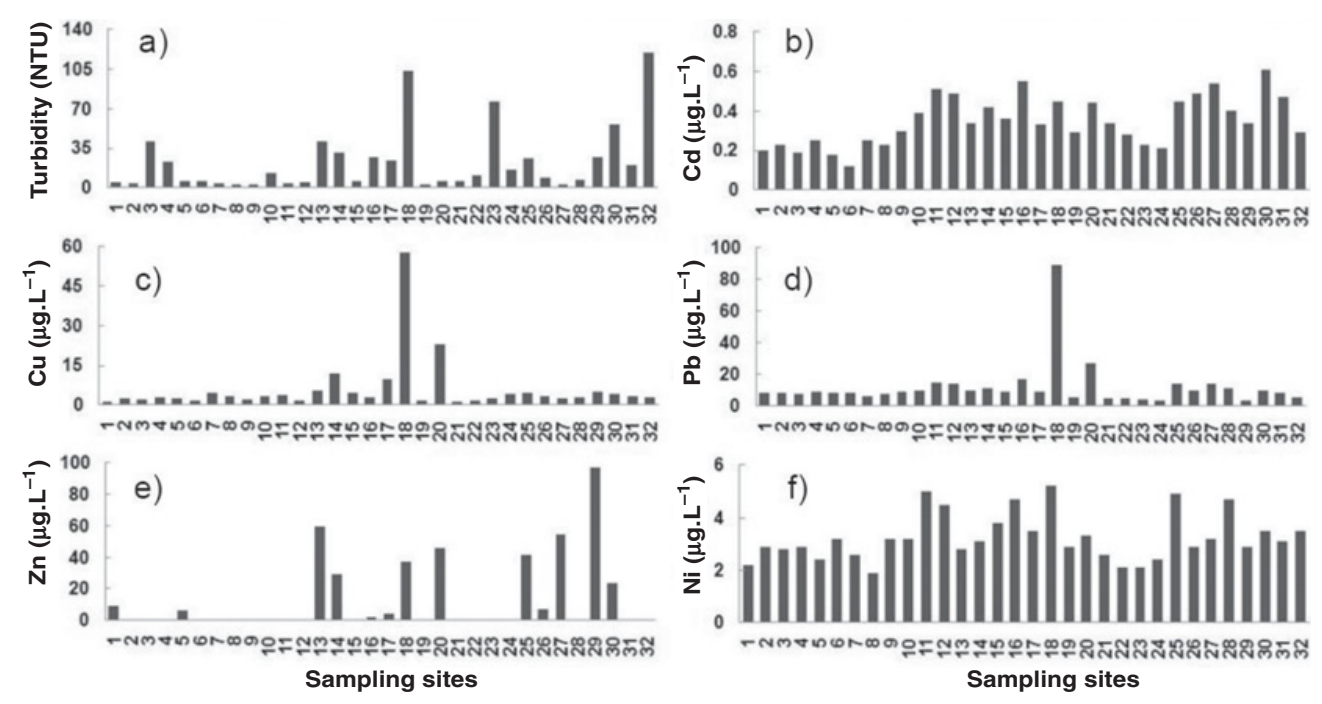

Fig. 2. Differences of environmental factors at each sampling site. a) Turbidity, b) DO, c) cadmium, d) copper, e) lead, f) zinc, g) nickel.

by the multi-response permutation procedure (MRPP), which is a non-parametric method for testing multivariate differences among pre-defined groups (Zimmerman et al., 1985). The Sørensen coefficient was used as the distance measure in the MRPP. The significance of the null hypothesis that there was no difference among the groups was tested with a Monte Carlo randomization procedure with 1000 permutations using PC-ORD software (McCune and Mefford, 1999). The differences of environmental variables among different clusters were evaluated using Dunn's multiple comparison tests after KruskalWallis (K-W) test through STATISTICA software (StatSoft, 2004). The community indices were also compared among different clusters by applying the K-W test.

The indicator value analysis (IndVal) (Dufrêne and Legendre, 1997) was used to define the indicator species for different clusters. The indicator value for each species in a group is the product of its relative abundance and its relative frequency $(\times 100)$, and ranges from 0 (no indication) to 100 (perfect indication) (Peterson and Keister, 2003). A perfect indicator of a particular group should be faithful and exclusive to that group, never occurring in another group (McCune and Grace, 2002). The significance of the indicator value for each species was tested with a Monte Carlo randomization procedure with 1000 permutations. The indicator values analysis was carried out with the PC-ORD software (McCune and Mefford, 1999).

NMDS was used to characterize differences of benthic macroinvertebrate communities and relations with their environmental factors. The NMDS technique appears to be superior to other ordination techniques when applied to ecological data (Kenkel and Orloci, 1986; Bettinetti et al., 2000; Kwon et al., 2009; Paule et al., 2009). NMDS was performed using PC-ORD (McCune and Mefford, 1999), based on the Bray-Curtis distance measure and 50 runs with a maximum of 100 iterations per run. A Monte Carlo test with 100 randomizations was used to determine the probability that the observed stress value of the final solution would occur by chance alone (Laughlin and Abella, 2007). To assist interpretation of the changes in community profiles, Spearman correlation coefficients between dimension scores and the environmental variables were calculated and plotted in the NMDS ordination using PC-ORD (McCune and Mefford, 1999).

Prior to the multivariate statistical analyses, those rare species occurring at only one site were excluded, and species densities were $\log (x+1)$ transformed to reduce variation.

\section{Results}

\section{Environmental characteristics}

The samples were collected from high mountain wadeable streams at an average elevation above sea level of $3144 \mathrm{~m}$, and most of the sampling sites reflected the shallow riffle habitats with width and depth of $8.4 \pm 5.6 \mathrm{~m}$ and $26 \pm 12 \mathrm{~cm}$, respectively (Table 1). The temperature was relatively low at most sampling sites $\left(9.0 \pm 3.3^{\circ} \mathrm{C}\right)$, whereas DO was relatively high $\left(11.7 \pm 1.5 \mathrm{mg} . \mathrm{L}^{-1}\right)$ (Table 1). TDS showed relatively high values in the Gangqu River $\left(90.3 \pm 31.0 \mathrm{mg} . \mathrm{L}^{-1}\right)$, whereas the values of chlorine, fluorine, calcium, and silicon dioxide were low. The lower concentrations of Chl- $a$ and $\mathrm{COD}_{\mathrm{Mn}}$ indicated lower nutrient levels in the Gangqu River.

The turbidity was relatively high with an average of $22.8 \pm 29.0$ NTU (Fig. 2a), showing the highest values at site 32 due to the erosion of the channel banks. The high turbidity at site 18 was mainly caused by mining activities at the upstream area. The concentrations of heavy metals at the sampling sites reflected the presence of mines at the upper reaches. The concentrations of $\mathrm{Cu}$ and $\mathrm{Pb}$ were significantly higher at sampling sites 18 and 20 located downstream of a mine (Figs. 1, 2c and 2d). The average 
Table 2. Spearman rank correlation coefficients of the environmental variables and community indices. SR: species richness.

\begin{tabular}{|c|c|c|c|c|c|c|}
\hline Variables & Turbidity & $\mathrm{Cd}$ & $\mathrm{Cu}$ & $\mathrm{Pb}$ & $\mathrm{Zn}$ & $\mathrm{Ni}$ \\
\hline Total abundance & -0.27 & $-0.38 *$ & -0.04 & $-0.58 * * *$ & $-0.42^{*}$ & -0.29 \\
\hline Total SR & $-0.57 * * *$ & -0.05 & $-0.40 *$ & -0.19 & $-0.35^{*}$ & -0.19 \\
\hline Ephemeroptera SR & -0.14 & 0.20 & -0.16 & 0.05 & -0.17 & 0.22 \\
\hline Plecoptera SR & $-0.67 * * *$ & -0.31 & $-0.44 *$ & -0.32 & -0.28 & $-0.41^{*}$ \\
\hline Trichoptera SR & $-0.43^{*}$ & 0.08 & $-0.39 *$ & -0.07 & -0.20 & -0.19 \\
\hline Shannon diversity index & $-0.47 * *$ & 0.25 & -0.34 & 0.21 & -0.03 & 0.10 \\
\hline Evenness & -0.27 & 0.31 & -0.25 & 0.28 & 0.11 & 0.15 \\
\hline Margalef richness index & $-0.38 *$ & 0.21 & $-0.36^{*}$ & 0.12 & -0.13 & 0.00 \\
\hline Collector-filter ( $\%)$ & $0.41 *$ & -0.13 & 0.06 & -0.33 & 0.02 & -0.19 \\
\hline Collector-gather $(\%)$ & 0.11 & 0.31 & 0.17 & 0.31 & 0.13 & 0.28 \\
\hline Predator $(\%)$ & $-0.42 *$ & 0.03 & -0.28 & 0.09 & -0.06 & -0.11 \\
\hline Scraper $(\%)$ & -0.27 & 0.04 & $-0.38 *$ & 0.11 & -0.33 & 0.22 \\
\hline Shredder $(\%)$ & -0.21 & 0.19 & 0.03 & 0.10 & 0.17 & 0.24 \\
\hline
\end{tabular}

$* p<0.05 ; * * p<0.01 ; * * *<0.001$.

concentration of $\mathrm{Zn}$ was $13.12 \pm 23.69 \mu \mathrm{g} . \mathrm{L}^{-1}$ (range $\left.0.00-97.30 \mu \mathrm{g} . \mathrm{L}^{-1}\right)$, showing the highest value at sampling site 29 (Figs. 1 and 2e). The average concentration of $\mathrm{Ni}$ was $3.25 \pm 0.89 \mu \mathrm{g} . \mathrm{L}^{-1}$ (range $1.90-5.20 \mu \mathrm{g} . \mathrm{L}^{-1}$ ), displaying the highest value at sampling site 18 (Fig. 2f). The concentration of $\mathrm{Cd}$ averaged $0.35 \pm 0.13 \mu \mathrm{g} . \mathrm{L}^{-1}$ (range $0.61-0.12 \mu \mathrm{g} . \mathrm{L}^{-1}$ ) with the highest value at sampling site 30 located at the lower reach of Hekou town, while the concentration was relatively low at the upper reach of Wengshui Stream (sampling sites 1-9) (Figs. 1 and 2b). Cd had relatively low concentration compared to other heavy metals. The high values of these heavy metals were likely due to the presence of active and/or formerly active mines upstream of the sampling sites (Fig. 1).

\section{Benthic macroinvertebrates}

A total of 86 taxa were identified in the sampling sites in the Gangqu River. Plecoptera, Ephemeroptera, Trichoptera (EPT), and Diptera comprised more than $89 \%$ of the total abundance. Baetis sp. and Cinygmula sp. (Ephemeroptera) were the most abundant taxa, reprensenting $14.5 \%$ and $9.1 \%$ of the total abundance, respectively. Turbidity was negatively correlated with community indices $(r=-0.38$ to $-0.57, p<0.05)$ with the expection of total abundance and Pielou's evenness (both $r=-0.27, p>0.05$ ) (Table 2). Among EPT, Plecoptera were the most strongly influenced by turbidity $(r=-0.67, p<0.001)$. However, correlations between heavy metals and relative abundance of FFGs were generally insignificant (Table 2).

Both total abundance and species richness were negatively correlated with heavy metals except $\mathrm{Ni}$. $\mathrm{Cu}$ concentration was negatively correlated with the relative abundance of scrapers indicating that increased $\mathrm{Cu}$ concentration induced a decrease of scrapers (Table 2). Total abundance was not significantly influenced by $\mathrm{Cu}$. Meanwhile, $\mathrm{Cd}$ and $\mathrm{Pb}$ reduced only total abundance without decreasing species richness. Zn decreased both total abundance and species richness, whereas Ni did not have significant effects on community indices with the exception of Plecoptera species richness $(r=-0.41$, $p<0.05)$. The correlation analysis revealed the highest effects of $\mathrm{Cu}$ on species richness $(r=-0.40, p<0.05)$, whereas $\mathrm{Pb}$ strongly influenced total abundance $(r=$ $-0.58, p<0.001)$.

Among the 86 taxa, 65 were selected based on an occurrence frequency exceeding 15\%. Of these 65 taxa, 27 displayed a significant negative correlation with heavy metals (Table 3). Cd had a negative influence on the abundance of eight taxa including Pericoma sp. $(r=-0.56, p<0.001)$ in Diptera and Peltoperlopsis sp. $(r=-0.52, p<0.01)$ in Plecoptera. $\mathrm{Cu}$ was negatively correlated with 12 taxa including Glossosoma $\mathrm{sp}$. $(r=$ $-0.56, p<0.001)$ in Trichoptera. $\mathrm{Pb}$ had a negative influence on 10 taxa including Simulium sp. $(r=-0.62$, $p<0.001)$ in Diptera and Apatania sp. $(r=-0.58$, $p<0.001)$ in Trichoptera. Zn influenced negatively 14 taxa including Cinygmula sp. $(r=-0.61, p<0.001)$ in Ephemeroptera and Tipula sp. $(r=-0.56, p<0.01)$ in Diptera. Ni decreased the abundance of eight taxa including Peltoperlopsis sp. $(r=-0.64, p<0.001)$ and Apatania sp. $(r=-0.54, p<0.01)$. Some taxa were adversely affected by most of the tested heavy metals, while the majority of taxa were affected by only one or two heavy metals. For example, Peltoperlopsis sp. had a significant negative correlation with $\mathrm{Cd}, \mathrm{Cu}, \mathrm{Pb}$, and $\mathrm{Ni}$ $(r=-0.44--0.64, p<0.05)$, and Pericoma sp. in Diptera was significantly decreased with $\mathrm{Cd}, \mathrm{Cu}, \mathrm{Zn}$, and $\mathrm{Ni}$ $(r=-0.42--0.56, p<0.05)$. Conversely, seven species were positively correlated with the concentration of the heavy metals. $\mathrm{Cd}$ had a positive correlation coefficient with seven species including Hydropsyche sp. $(r=0.62$, $p<0.001)$ in Trichoptera, and Ephemera sp. $(r=0.53$, $p<0.01)$ in Ephemeroptera. Meanwhile 31 taxa did not display significant correlation coefficients with heavy metals $(r<0.344, p>0.05)$. 
Table 3. Spearman rank correlation coefficients between heavy metals and selected taxa, and indicator species in each cluster.

\begin{tabular}{|c|c|c|c|c|c|c|c|c|c|}
\hline & \multirow[b]{2}{*}{ Taxa } & \multirow{2}{*}{$\begin{array}{c}\text { Occurrence } \\
\text { frequency } \\
(\%)\end{array}$} & \multicolumn{5}{|c|}{ Correlation coefficients } & \multicolumn{2}{|c|}{$\begin{array}{c}\text { Indicator species } \\
\text { analysis } \\
\end{array}$} \\
\hline & & & $\mathrm{Cd}$ & $\mathrm{Cu}$ & $\mathrm{Pb}$ & $\mathrm{Zn}$ & $\mathrm{Ni}$ & $\begin{array}{l}\text { Indicator } \\
\text { values }\end{array}$ & $\begin{array}{l}\text { Indicating } \\
\text { cluster }\end{array}$ \\
\hline \multirow{6}{*}{ Plecoptera } & Stavsolus sp. & 53.1 & -0.30 & $-0.49 * *$ & -0.18 & $-0.44 *$ & -0.16 & $39.8^{*}$ & I \\
\hline & Nemoura sp. & 71.9 & -0.34 & $-0.44 *$ & -0.26 & $-0.42 *$ & -0.25 & $33.0 * *$ & I \\
\hline & Suwallia sp. & 93.8 & $-0.39 *$ & -0.29 & $-0.47 * *$ & $-0.38 *$ & $-0.39 *$ & $25.0^{*}$ & I \\
\hline & Papacapnia sp. & 53.6 & $0.37 *$ & -0.21 & 0.30 & -0.14 & 0.20 & $55.8^{*}$ & VI \\
\hline & Capnia sp. & 62.5 & -0.23 & 0.12 & $-0.37 *$ & 0.06 & -0.32 & - & - \\
\hline & Peltoperlopsis sp. & 68.8 & $-0.52 * *$ & $-0.50^{* *}$ & $-0.44^{*}$ & -0.19 & $-0.64 * * *$ & - & - \\
\hline \multirow{7}{*}{$\begin{array}{l}\text { Epheme- } \\
\text { roptera }\end{array}$} & Baetis sp.1 & 100.0 & -0.04 & -0.30 & 0.00 & $-0.37 *$ & 0.13 & $31.0^{*}$ & I \\
\hline & Serratella sp. & 75.0 & 0.15 & -0.13 & -0.22 & -0.29 & -0.02 & $34.4^{* *}$ & II \\
\hline & Cinygmula sp. & 93.8 & -0.08 & $-0.44 *$ & -0.26 & $-0.61 * * *$ & -0.04 & $26.3^{* *}$ & IV \\
\hline & Ephemera sp. & 57.5 & $0.53 * *$ & 0.17 & 0.34 & 0.15 & $0.56 * * *$ & $27.1 *$ & VI \\
\hline & Epeorus sp. & 96.9 & $-0.44^{*}$ & -0.11 & $-0.40 *$ & -0.33 & -0.28 & - & - \\
\hline & Rhithrogena sp. & 53.1 & -0.13 & -0.21 & -0.01 & $-0.45^{* *}$ & 0.07 & - & - \\
\hline & Siphluriscus sp. & 53.1 & 0.06 & $-0.37^{*}$ & 0.10 & -0.35 & 0.08 & - & - \\
\hline \multirow[t]{13}{*}{ Trichoptera } & Rhyacophila sp.1 & 81.3 & -0.03 & $-0.47 * *$ & -0.04 & $-0.43^{*}$ & -0.12 & $31.7 *$ & II \\
\hline & Sericostriata sp. & 58.8 & -0.15 & -0.35 & $-0.39 *$ & $-0.40 *$ & -0.22 & $44.3^{*}$ & II \\
\hline & Brachycentrus sp. & 68.8 & -0.09 & 0.35 & -0.34 & 0.17 & -0.27 & $43.4^{* *}$ & VI \\
\hline & Apatania sp. & 53.8 & -0.33 & -0.04 & $-0.58 * * *$ & -0.02 & $-0.54 * *$ & - & - \\
\hline & Apsilochorema sp. & 53.1 & $0.41 *$ & $0.37^{*}$ & 0.28 & 0.18 & $0.45 * *$ & - & - \\
\hline & Ecclisomyia sp. & 55.0 & -0.30 & -0.09 & -0.32 & -0.18 & $-0.42 *$ & - & - \\
\hline & Glossosoma sp. & 56.3 & $-0.52 * *$ & $-0.56^{* * *}$ & $-0.37 *$ & -0.32 & -0.34 & - & - \\
\hline & Himalopsyche sp. & 59.4 & -0.10 & $-0.51 * *$ & -0.05 & $-0.38 *$ & -0.10 & - & - \\
\hline & Hydropsyche sp. & 57.5 & $0.62 * * *$ & 0.10 & $0.46 * *$ & 0.14 & $0.37 *$ & - & - \\
\hline & Lepidostoma sp. & 71.9 & -0.31 & 0.07 & $-0.38 *$ & -0.05 & $-0.37 *$ & - & - \\
\hline & Parapsyche sp. & 58.8 & -0.10 & $-0.38^{*}$ & -0.14 & 0.06 & $-0.38 *$ & - & - \\
\hline & Polycentropus sp. & 68.8 & $0.42 *$ & 0.03 & $0.39^{*}$ & 0.09 & $0.55^{* *}$ & - & - \\
\hline & Tinodes sp. & 57.5 & $0.41^{*}$ & -0.13 & 0.32 & -0.07 & $0.41 *$ & - & - \\
\hline \multirow[t]{6}{*}{ Diptera } & Pericoma sp. & 59.4 & $-0.56 * * *$ & $-0.52 * *$ & -0.31 & $-0.42 *$ & $-0.45^{*}$ & $40.0 *$ & I \\
\hline & Empididae sp. & 81.3 & $-0.37 *$ & 0.04 & -0.18 & -0.14 & -0.28 & $30.4 *$ & $\mathrm{I}$ \\
\hline & Tipula sp. & 50.0 & 0.23 & -0.08 & -0.12 & -0.25 & 0.31 & $46.8 * *$ & IV \\
\hline & Atherix sp. & 100.0 & $-0.53 * *$ & -0.07 & $-0.45 * *$ & -0.25 & $-0.44^{*}$ & - & - \\
\hline & Deuterophlebia sp. & 65.0 & -0.28 & -0.13 & -0.18 & $-0.36^{*}$ & 0.03 & - & - \\
\hline & Simulium sp. & 81.3 & $-0.50 * *$ & -0.22 & $-0.62 * * *$ & -0.34 & -0.33 & - & - \\
\hline \multirow[t]{5}{*}{ Others } & Macronychus sp. & 90.6 & 0.16 & -0.13 & -0.18 & -0.25 & -0.06 & $31.2 * *$ & II \\
\hline & Microcylloepus sp. & 40.6 & 0.12 & - & - & - & - & $42.8 *$ & II \\
\hline & Gammarus sp. & 37.5 & -0.01 & - & - & - & - & $58.0 * * *$ & IV \\
\hline & Dugesia sp. & 59.4 & $0.44^{*}$ & 0.21 & $0.41 *$ & 0.28 & $0.41 *$ & - & - \\
\hline & Araneae sp. & 65.6 & -0.27 & -0.31 & -0.26 & $-0.51 * *$ & -0.19 & - & - \\
\hline
\end{tabular}

$* p<0.05 ; * * p<0.01 ; * * * p<0.001$.

\section{Multivariate analyses}

The dataset composed of 32 sampling sites with 65 selected taxa displaying more than $15 \%$ of occurrence frequency were used in the multivariate analyses. Thirtytwo sampling sites were classified into six clusters (I-VI) based on the similarities of community composition (Fig. 3). MRPP revealed significant differences among the clusters $(\mathrm{A}=0.137, p<0.001)$. Overall, the classification reflected influences of the geographical location of sampling sites as well as heavy metals. Cluster I included sampling sites 1-9 (except site 4) located at the upper reach of the Wengshui Stream, and cluster II included samples mainly from the upstream area of the Geza Stream (Figs. 1 and 3). Sampling sites in clusters III and IV were located at the lower reaches of mines, reflecting the difference of benthic macroinvertebrate communities compared with other sites. Cluster V included seven sampling sites from relatively downstream areas, and cluster VI included four sampling sites located at the main channel of the Geza Stream (Fig. 3).

Through the indicator species analysis, each cluster was characterized with different taxa (Table 3). The indicator 


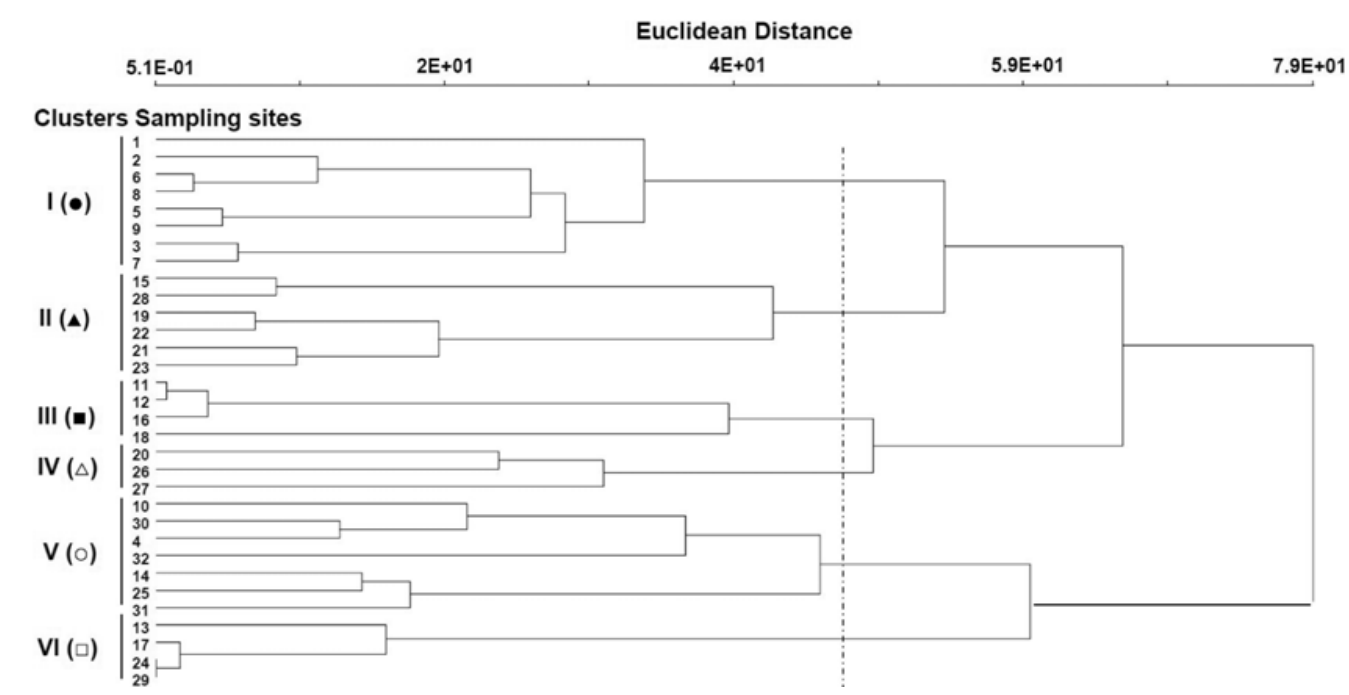

Fig. 3. Classification of the sampling sites with benthic macroinvertebrate communities based on a hierarchical cluster analysis using Ward's linkage method with Euclidean distance measure. Geographical distribution of sampling sites was indicated in Figure 1.
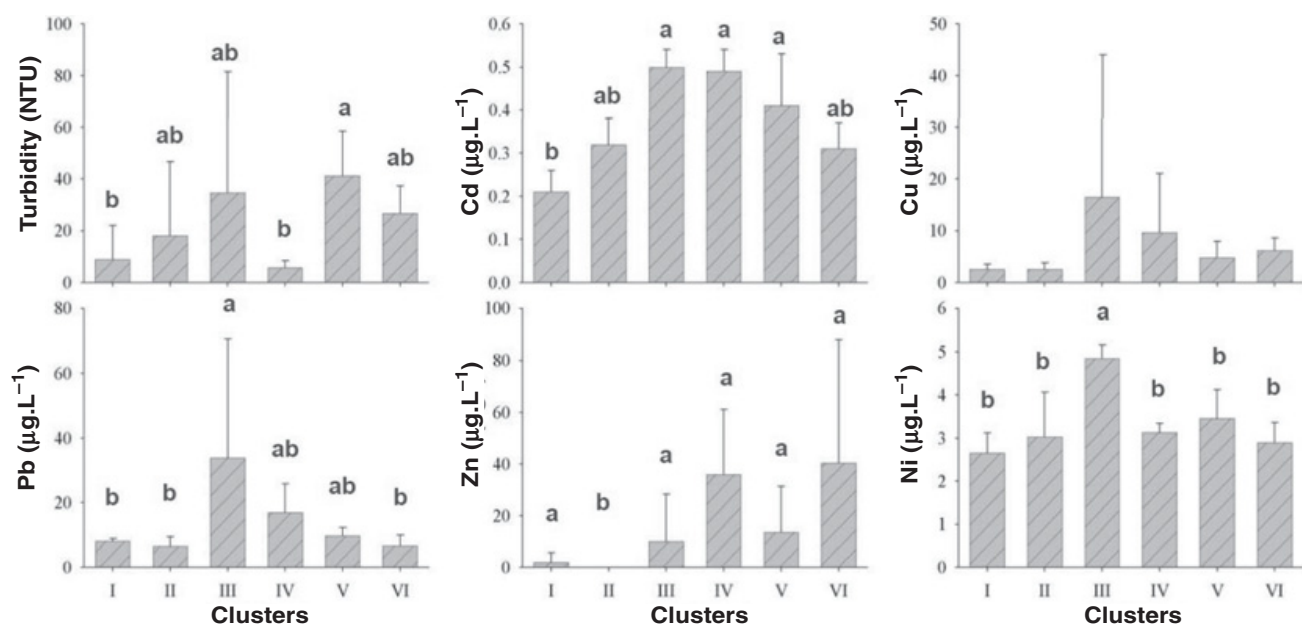

Fig. 4. Differences of heavy metals concentrations and turbidity level at different clusters. The error bars are standard deviation of each variable. The same letter on the error bars indicates no significant differences $(p<0.05)$ among clusters based on the non-parametric Dunn tests.

species were mainly Plecoptera, Ephemeroptera, and Trichoptera for clusters I, II, IV, and VI. However, the indicator species for clusters III and V were not identified. Six taxa including Pericoma sp. were identified as indicator species for cluster I, five taxa including Sericostriata sp. were indicator species for cluster II, three taxa including Gammarus sp. were identified as indicator species for cluster IV. Finally, three taxa including Paracapnia sp. characterized cluster VI (Table 3). Six taxa including Pericoma sp., Stavsolus sp., and Sericostriata sp. in clusters I and II were negatively correlated with contamination by heavy metals $(r=-0.39--0.56, p<0.05)$. In contrast, four taxa including Paracapnia sp. $(r=0.37, p<0.05$ with $\mathrm{Cd})$ and Ephemera sp. $(r=0.53, p<0.01$ with $\mathrm{Cd}$, and $r=0.53, p<0.001$ with $\mathrm{Ni}$ ) in cluster VI were positively correlated with heavy metals (Table 3 ).
Turbidity was significantly higher in cluster V (41.34 NTU) than in clusters I and IV (5.70-8.85 NTU) (K-W test, $p<0.05$ ), whereas other physical (i.e., stream width and depth, altitude, velocity, and temperature) and chemical-environmental factors (DO) were not significantly different among clusters (Fig. 4). For the heavy metals, Cd had significantly higher values in clusters III, IV and V $\left(0.41-0.50 \mu \mathrm{g} . \mathrm{L}^{-1}\right)$ compared with cluster I $\left(0.21 \mu \mathrm{g} . \mathrm{L}^{-1}\right)(\mathrm{K}-\mathrm{W}$ test, $p<0.001)$. $\mathrm{Pb}$ was also significantly higher in cluster III $\left(33.93 \mu \mathrm{g} . \mathrm{L}^{-1}\right)$ than in clusters I, II and VI $\left(6.58-8.09 \mu \mathrm{g} . \mathrm{L}^{-1}\right)(\mathrm{K}-\mathrm{W}$ test, $p<0.01)$, and the $\mathrm{Zn}$ concentration was significantly lower in cluster II than in other clusters (K-W test, $p=0.05$ ). $Z n$ was not detected at sampling sites in cluster II, while it was the highest in cluster VI $\left(40.35 \mu \mathrm{g} . \mathrm{L}^{-1}\right)$. Ni was significantly higher in cluster III $\left(4.85 \mu \mathrm{g} . \mathrm{L}^{-1}\right)$ compared with 

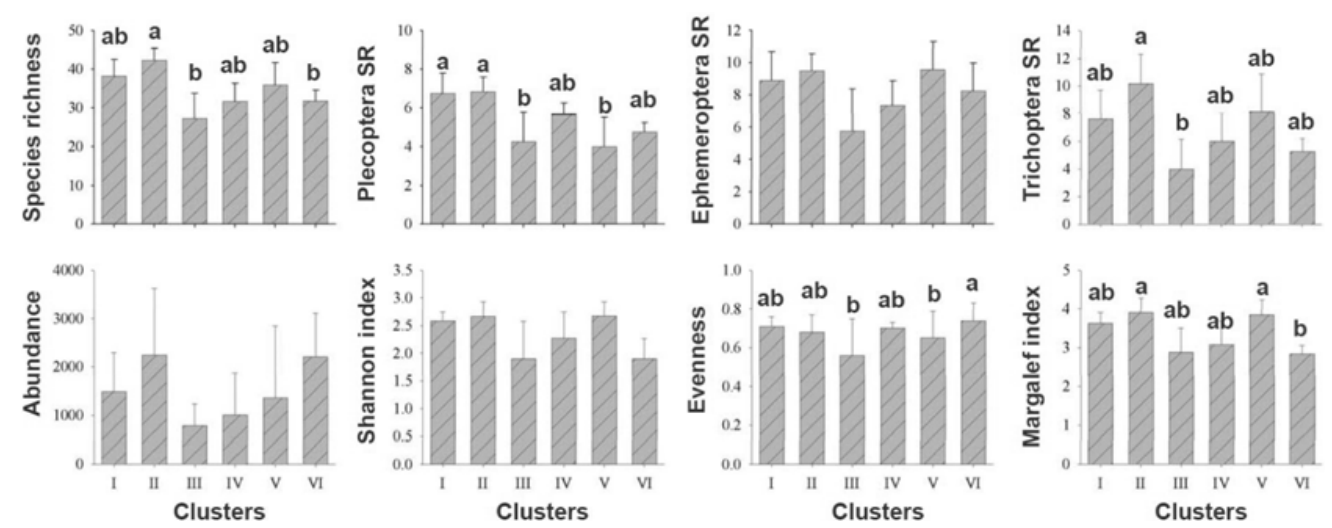

Fig. 5. Community indices at different clusters. The error bars are standard deviation of each variable. The same letter on the error bars indicates no significant differences $(p<0.05)$ among clusters based on the non-parametric Dunn tests.

other clusters $\left(2.65-3.46 \mu \mathrm{g} . \mathrm{L}^{-1}\right)(\mathrm{K}-\mathrm{W}$ test, $p<0.05)$. $\mathrm{Cu}$ was not significantly different among different clusters, although it was relatively higher in cluster III $\left(16.53 \mu \mathrm{g} . \mathrm{L}^{-1}\right)$ than in other clusters $\left(2.48-9.60 \mu \mathrm{g} . \mathrm{L}^{-1}\right)$ (Fig. 4). The sampling sites contaminated with $\mathrm{Cd}, \mathrm{Cu}, \mathrm{Pb}$, and Ni were mainly found in cluster III, whereas sampling sites influenced by $\mathrm{Zn}$ were in clusters IV and VI.

The species richness was significantly lower in clusters III (27 taxa) and VI (32 taxa) than in cluster II (42 taxa) (Fig. 5). Species richness of Plecoptera was significantly lower in clusters V and III (each with four species) compared with cluster I (seven species of Plecoptera), and species richness of Trichoptera was significantly lower in cluster III (four taxa) than in cluster II (10 taxa). Evenness was significantly higher in cluster VI (0.74) than in cluster III and V (0.65) (K-W test, $p=0.044)$, whereas Margalef's index was lower in cluster VI (2.83) compared with clusters II and V (3.85-3.91) (K-W test, $p<0.01)$. The species richness of Ephemeroptera, total abundance, and Shannon diversity index showed no significant differences among clusters (Fig. 5).

Two-dimensional NMDS ordination was obtained with 15.26 of final stress and 0.00 of final instability (Fig. 6). The axes explained significantly more variance than would be expected by chance, based on Monte Carlo permutation tests $(p=0.01)$. Clusters defined by cluster analysis (Fig. 3) were well-reflected in the NMDS ordination plots. The sampling sites of clusters I and II were mainly distributed in the upper middle part of the ordination map, and the sampling sites of cluster III were in the left part. In particular, sampling site 18 which suffered from the highest contamination of $\mathrm{Pb}$ and $\mathrm{Cu}$ (Fig. 2) was separated from other sites in the far left. The sampling sites of cluster IV were at the upper part of the map, the sampling sites of cluster $\mathrm{V}$ were in the lower middle part, and the sampling sites of cluster VI were mainly in the lower right area of the map.

The effects of environmental variables were characterized by calculating correlation coefficients between environmental factors and NMDS axis scores. The variables having significant correlation coefficients $(r<0.344$, $p<0.05)$ are shown as arrows on the NMDS ordination
(Fig. 6a), where the arrow length indicates the magnitude of the correlation value and the arrow direction implies a correlation with each axis. Axis 1 was highly correlated with $\mathrm{Pb}(r=-0.634, p<0.001)$ and $\mathrm{Cu}(r=-0.527$, $p<0.01$ ), thus showing the effects of heavy metals on benthic macroinvertebrate communities. Axis 2 was positively correlated with altitude thus showing the upto downstream distribution of sites $(r=0.609, p<0.001)$, but it was negatively correlated with width $(r=-0.612$, $p<0.001)$, turbidity $(r=-0.602, p<0.001)$, and temperature $(r=-0.499, p<0.01)$.

The clusters I and II displayed high relations with higher altitude and low values for turbidity, width, and temperature. In contrast, cluster V had higher turbidity, width, and temperature at lower altitude. Cluster III was explained by high values of heavy metals, indicating strong effects of heavy metal contamination on the species composition, especially at site 18 (Figs. 2 and 6a). The sampling site 26 , located on the left part with high correlation with $\mathrm{Pb}$ and $\mathrm{Cu}$, also reflected the effects of heavy metals. The sampling site 30 revealed high value of Cd. The cluster IV was in the upper part (high altitude), and the cluster $\mathrm{V}$ was at the middle part with high values for turbidity, stream width, and velocity.

Using the NMDS analysis, species could be ordinated on the biplot based on their contribution to the community ordination (Fig. 6b), reflecting their occurrence at different sites. The results were consistent with the IndVal analysis conducted to evaluate indicative species for each cluster. Most of the species negatively correlated with heavy metals were mainly distributed at the upper right part of the NMDS ordination (Fig. 6b). The indicator taxa of cluster I including Pericoma sp. and Stavsolus sp. were in the upper part of the map, whereas the indicator taxa of cluster II including Sericostriata sp. and Rhyacophila sp. were in the middle upper part. The indicator taxa of cluster VI including Paracapnia sp. and Ephemera sp. were in the right part of the map. The species sensitive to heavy metals such as Peltoperlopsis sp. (Table 3) were in the uppermost area. In general, all the sensitive species distributed at the reverse direction of the heavy metals contamination. In contrast, the tolerant species 

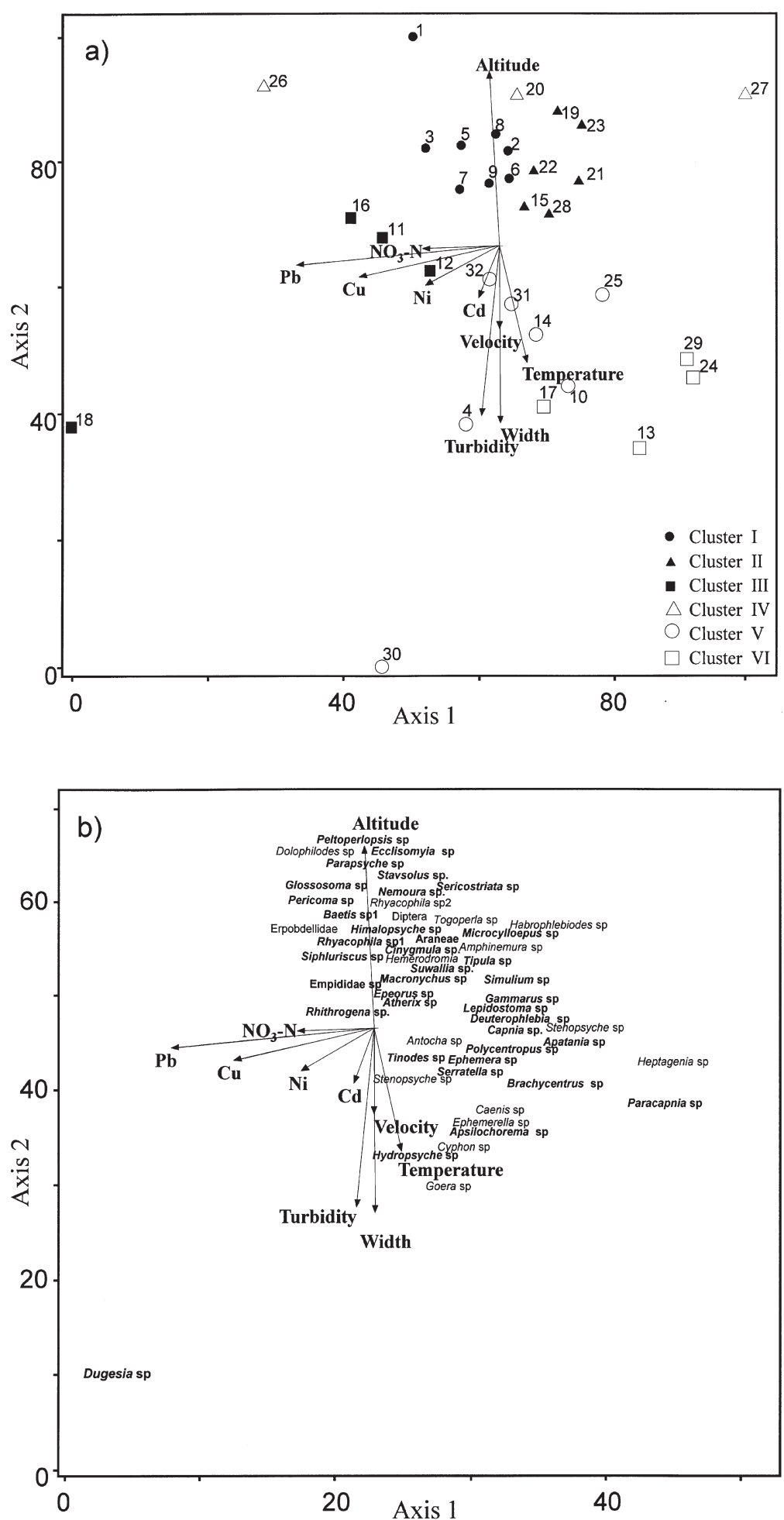

Fig. 6. NMDS ordination with benthic macroinvertebrate communities and environmental factors. a) Ordination of the sampling sites with significant environmental factors, and b) ordination of taxa with significant environmental factors. Correlation coefficients between ordination scores of each axis and environmental factors were calculated and visualized on the ordination plot. The sampling sites of different clusters defined in Figure 3 are indicated by different symbols. Indicator taxa were expressed as a bold type.

Paracapnia sp., Hydopsyche sp., Ephemera sp., Polycentropus sp., and Apsilochorema sp. were distributed in the middle and lower parts of the plot and positively correlated with $\mathrm{Cd}$ concentration $(r=0.37-0.62, p<0.05)$, whereas
Dugesia sp., which was distributed at the lower left part of the plot, displayed positive correlation with $\mathrm{Pb}(r=0.41$, $p<0.05$ ) (Table 3, Fig. 6b). The location of Dugesia sp. in the NMDS biplot matched the location of site 18 
(cluster III), Paracapnia sp. matched heavy metalcontaminated sites 24 and 29 (cluster VI), and Ephemera sp., Polycentropus sp. and Apsilochorema sp. matched the location of sites 25, 14 and 31 (cluster V) (Fig. 6b).

\section{Discussion}

\section{Low level contamination of heavy metals}

The Gangqu River, in the high mountain area of Shangrila Gorge of China, has been impacted by heavy metals released from presently and formerly active mines. Presently, we observed an increase in $\mathrm{Zn}, \mathrm{Cu}$, and $\mathrm{Pb}$ concentrations $\left(>20 \mu \mathrm{g} . \mathrm{L}^{-1}\right)$ at sampling sites downstream of active and previously active mines, as compared with unpolluted areas that were not downstream of mines. According to the Chinese Environmental Quality Standards for Surface Water (Ministry of Environmental Protection, 2002), the concentrations of heavy metals measured in the sampling sites belonged to classes I and II representing freshwaters of headstreams or national reserves, and reserve area for resident drinking water, respectively. This indicated that contamination by heavy metals was not a serious problem in the study area. However, the deleterious effects of the contaminating heavy metals on macroinvertebrate communities in the Shangrila region watercourses resulted in reduced species richness and changes of the community compositions. The responses of these communities to heavy metals are both severe (Kiffney and Clements, 1996) and unrecoverable (van Damme et al., 2008) in high mountain streams. Thus, it is conceivable that the low levels of heavy metals presently documented in some watercourses might profoundly affect the biological diversity and thus the ecological health of the affected streams.

\section{Various responses of macroinvertebrates}

In this study, the effects of heavy metals on macroinvertebrates were reflected in differences of community indices as well as community composition. Total abundance, species richness, and richness of Plecoptera and Trichoptera showed strong negative correlations with heavy metals (Table 2), reflecting the negative effects of heavy metals on stream ecosystems. In contrast, species richness of Ephemeroptera was not significantly decreased by heavy metals levels. However, heavy metal-related deleterious effects on Ephemeroptera have been reported (Specht et al., 1984; Clements, 1994), mostly affected sensitive species (Clements et al., 1988; Clements, 1994).

Heavy metal sensitivity of Ephemeroptera, Plecoptera, and Trichoptera species were apparent at the genus level. Peltoperlopsis sp. (Plecoptera) responded the most sensitively, especially with Ni. In Ephemeroptera, Cinygmula sp. was the most sensitive species, especially to $\mathrm{Zn}$. Baetis sp. abundance decreased with $\mathrm{Zn}$ levels, in accordance with previous observations (Clements et al.,
1988). Contrarily, heavy metal tolerance of Baetis sp. has been reported (Beasley and Kneale, 2002; van Damme et al., 2008). Even at low concentrations of $\mathrm{Zn}$, Rhithrogena hageni showed significantly decreasing abundances, and was recorded as a sensitive species (Nelson and Roline, 1996). In Trichoptera, Rhyacophila sp. displayed negative responses to $\mathrm{Cu}$ and $\mathrm{Zn}$. Similar results, showing decreased population density or absence in high altitude streams, were reported by Kiffney and Clements (1996). Considering the effects of different heavy metals, Pericoma and Simulium sp. in Diptera were sensitive to $\mathrm{Cd}$ and $\mathrm{Pb}$, respectively.

Meanwhile, some taxa responded positively to increased concentrations of heavy metals. The abundance of Paracapnia sp. in Plecoptera increased significantly with increasing $\mathrm{Cd}$ concentration. In Trichoptera, the abundance of Polycentropus sp., Tinodes sp., Hydropsyche sp., and Apsilochorema sp. increased as a function of concentrations of heavy metals, especially $\mathrm{Cd}$ and $\mathrm{Ni}$. The tolerance of Trichoptera, especially Hydropsyche, to heavy metals has been well reported (Clements and Kiffney, 1994; Clements et al., 2000). Dugesia sp. in Turbellaria displayed positive correlations with concentrations of $\mathrm{Cd}$, $\mathrm{Pb}$, and $\mathrm{Ni}$, although correlation coefficients were low. Correspondingly, Dugesia sp. was the second species in terms of density at site 18 (36 ind. $\left.\mathrm{m}^{-2}\right)$ and 20 (12 ind. $\mathrm{m}^{-2}$ ). Fennikoh et al. (1978) reported that Dugesia was not very sensitive to $\mathrm{Cd}$. Therefore, our results contrasted with previous reports (Malard et al., 1996). This may indicate that the concentrations of the heavy metals were lower than those critical concentrations that lead to decreases in abundance. These organisms are not only tolerant to heavy metal contamination but also to the conditions created by them (van Damme et al., 2008). High numbers of tolerant species in contaminated areas may also be due to the absence of heavy metal sensitive predators (Weatherley et al., 1980).

In the evaluation of community indices, only the Margalef richness index and percentage of scrapers in FFGs showed significantly negative correlations with $\mathrm{Cu}$. These results are supported by bioassessments of contaminated sites that demonstrated strong correlations with heavy metals (Gray and Delaney, 2008; van Damme et al., 2008). However, it should be noted that other studies did not report significant correlations between heavy metals and biological indices such as the Shannon diversity index and percentage composition of FFGs (Weigel et al., 2002; Gray and Delaney, 2008). Thus, diversity indices such as the Shannon diversity index may not be suitable assessment tools due to their instability (Watanabe et al., 2008). Moreover, the usefulness of FFGs could change for different streams due to the different trophic structures and sensitivities the corresponding species.

The clustering of macroinvertebrate communities based on species composition apparently reflected the natural characteristics of streams, and the effects of mines (Figs. 3 and 4). For instance, the sampling sites of clusters $\mathrm{V}$ and VI were located at the downstream area or main reach of the Gangqu River. Meanwhile, the sampling sites 
of clusters III and IV were all located downstream of active or closed mines. According to the NMDS results, temperature, turbidity, stream width and velocity at low altitude were the main influential factors distinguishing the sampling sites in clusters V and VI from other sampling sites (Fig. 6a). Communities were characterized by relatively high altitude in clusters I, II, and IV. Altitude is a key factor to explain longitudinal changes in species composition, especially in mountain streams (Vannote et al., 1980; Ward, 1994; Maiolini and Lencioni, 2001; Hollmann and Miserendino, 2008). The axis 1 of NMDS ordination showed the effects of heavy metals on benthic macroinvertebate communities (Fig. 6a), characterizing cluster III with high concentrations of $\mathrm{Pb}$ and $\mathrm{Cu}$. Correspondingly, the species richness was low in cluster III compared with cluster II. Meanwhile, Trichoptera species in particular showed a significant decrease in cluster III (Fig. 5). The location of sensitive and tolerant species in the NMDS ordination was in accordance with the correlation analysis between the species and heavy metals (Table 3, Fig. 6b). For example, Rhithrogena sp. and Siphluriscus sp. were located mainly in the middle upper part in the NMDS biplot with lower concentration of heavy metals. However, Dugesia sp., Paracapnia sp. and Ephemera sp. were distributed in the lower middle part of the NMDS biplot showing extensive contamination of heavy metals (Fig. 6b). Meanwhile, the location of tolerant species on the biplot also matched the site locations of cluster III, V, and VI (Fig. 6a). The NMDS results thus coincided well with that of the cluster analysis.

Considering the differences of physical-chemical environmental factors including heavy metals among different clusters (Fig. 4), turbidity and heavy metals were significantly different among the different clusters. Turbidity correlated significantly with $\mathrm{Cu}$ and $\mathrm{Pb}$, suggesting that high turbidity results from the erosion associated with mining activities. Therefore, the effects of high turbidity might be reflected in the heavy metal-related changes of benthic macroinveretebrate communities.

In conclusion, the effects of several environmental factors such as geographical, hydromorphological, physi$\mathrm{cal}$, and chemical factors including heavy metals were revealed through both distributional and compositional patterns of benthic macroinvertebrates in high mountain streams. Although the effects were compounded with different factors such as altitude, temperature, stream width, turbidity, and heavy metals, the influence of heavy metals on benthic macroinvertebrate communities was clearly identified, with a decrease in species richness and changes in species composition. Even though contamination by heavy metals was low in the sampling area, the consequences upon benthic diversity were significant, indicating that the chronic effects of long-term exposure of aquatic communities to heavy metals could be serious in high mountain streams.

Acknowledgements. This research was supported by the Kyung Hee University Post-Doctoral Research Associate Fund in 2008
(KHU-20080279). The ecological data were obtained through the Key Project of National Natural Science Foundation of China (No. 30330140) and the Knowledge Innovation Program of the Chinese Academy of Sciences (No. KZCX2-YW-427).

\section{References}

APHA, 1992. Standard Methods for the Examination of Water and Wastewater, 18th edition, American Public Health Association, New York.

Beasley G. and Kneale P., 2002. Reviewing the impact of metals and PAHs on macroinvertebrates in urban water courses. Progr. Phys. Geogr., 26, 236-270.

Beltman D.J., Clements W.H., Lipton J. and Cacela D., 1999. Benthic invertebrate metals exposure, accumulation and community-level effects downstream from a hardrock mine site. Environ. Toxicol. Chem., 18, 299-307.

Bettinetti R., Morabito G. and Provini A., 2000. Phytoplankton assemblage structure and dynamics as indicator of the recent trophic and biological evolution of the western basin of Lake Como (N. Italy). Hydrobiologia, 435, 177-190.

Carlisle D.M. and Clements W.H., 1999. Sensitivity and variability of metrics used in biological assessments of running waters. Environ. Toxicol. Chem., 18, 285-291.

Carlisle D.M. and Clements W.H., 2003. Growth and secondary production of aquatic insects along a gradient of $\mathrm{Zn}$ contamination in Rocky Mountain streams. J. N. Am. Benthol. Soc., 22, 582-597.

Carpenter K.E., 1924. A study of the fauna of rivers polluted by lead mining in the Aberstwyth district of Cardiganshire. Ann. Appl. Biol., 11, 1-23.

Cherry D.S., Currie R.J., Soucek D.J., Latimer H.A. and Trent G.C., 2001. An integrative assessment of a watershed impacted by abandoned mined land discharges. Environ. Pollut., 111, 377-388.

Chinese Environmental Protection Chief Bureau, 2002. Water and Wastewater Monitoring and Analysis Association, Standard Methods for the Examination of Water and Wastewater $[\mathrm{M}]$, 4th edition, Chinese Environmental Sciences Press, Beijing.

Clements W.H., 1994. Benthic invertebrate community responses to heavy metals in the Upper Arkansas River Basin; Colorado. J. N. Am. Benthol. Soc., 13, 30-44.

Clements W.H., 1999. Metal tolerance and predator-prey interactions in benthic macroinvertebrate stream communities. Ecol. Appl., 9, 1073-1084.

Clements W.H. and Kiffney P.M., 1994. Integrated laboratory and field approach for assessing impacts of heavy metals at the Arkansas River, Colorado. Environ. Toxicol. Chem., 13, 397-404.

Clements W.H., Cherry D.S. and Cairns Jr. J., 1988. The impact of heavy metals on macroinvertebrate communities: a comparison of observational and experimental results. Can. J. Fish. Aquat. Sci., 25, 2017-2025.

Clements W.H., Carlisle D.M., Lazorchak J.M. and Johnson P.C., 2000. Heavy metals structure benthic communities in Colorado Mountain streams. Ecol. Appl., 10, 626-638.

Clifford H.T. and Stephenson W., 1975. An Introduction to Numerical Classification, Academic Press, London. 
Dufrêne M. and Legendre P., 1997. Species assemblages and indicator species: the need for a flexible asymmetrical approach. Ecol. Monogr., 67, 345-366.

Fennikoh K.B., Hishfield H.I. and Kneip T.J., 1978. Cadmium toxicity in planktonic organisms of a freshwater food web. Environ Res., 15, 357-367.

Freund J.G. and Petty J.T., 2007. Response of fish and macroinvertebrate bioassessment indices to water chemistry in a mined Appalachian watershed. Environ. Manag., 39, 707-720.

Gray N.F. and Delaney E., 2008. Comparison of benthic macroinvertebrate indices for the assessment of the impact of acid mine drainage on an Irish river below an abandoned Cu-S mine. Environ. Pollut., 155, 31-40.

Hollmann M.E.T. and Miserendino M.L., 2008. Life history and emergence patterns of stonefly species in mountain streams of the Futaleufú basin, Patagonia (Argentina). Ann. Limnol. - Int. J. Lim., 44, 135-144.

Huang X.F., 1999. Survey, Observation and Analysis of Lake Ecology, Standards Press of China, Beijing (in Chinese).

Jiang W.X., Tang T., Jia X.H., Wu N.C., Duan S.G., Li D.F. and Cai Q.H., 2008. Impacts of acid pyrite drainage on the macroinvertebrate community in Gaolan River. Acta Ecol. Sin., 28, 4805-4814 (Chinese with English abstract).

Kenkel N.C. and Orloci L., 1986. Applying metric and nonmetric multidimensional scaling to ecological studies: some new results. Ecology, 67, 919-928.

Kiffney P.M. and Clements W.H., 1996. Effects of metals on stream macroinvertebrate assemblages from different altitudes. Ecol. Appl., 6, 472-481.

Kwon Y.S., Hwang S.J., Park K.S., Kim H.S., Kim B.H., Shin K.H., An K.G., Song Y.H. and Park Y.S., 2009. Temporal changes of phytoplankton community at different depths of a shallow hypertrophic reservoir in relation to environmental variables. Ann. Limnol. - Int. J. Lim., 45, 93-105.

Laughlin D.C. and Abella S.R., 2007. Abiotic and biotic factors explain independent gradients of plant community composition in ponderosa pine forests. Ecol. Model., 205, 231-240.

Maiolini B. and Lencioni V., 2001. Longitudinal distribution of macroinvertebrate assemblages in a glacially influenced stream system in the Italian Alps. Freshwat. Biol., 21, $1625-1639$.

Malard F., Plenet S. and Gibert J., 1996. The use of invertebrates in ground water monitoring: a rising research field. Ground Water Monit. Remed., 16, 103-113.

Malmqvist B. and Hoffsten P., 1999. Influence of drainage from old mine deposits on benthic macroinvertebrate communities in central Swedish streams. Water Res., 33, 2415-2423.

Maret T.R., Cain D.J., MacCoy D.E. and Short T.M., 2003. Response of benthic invertebrate assemblages to metal exposure and bioaccumulation associated with hard-rock mining in northwestern streams USA. J. N. Am. Benthol. Soc., 22, 598-620.

McCune B. and Grace J.B., 2002. Analysis of Ecological Communities, MjM Software Design, Gleneden Beach, Oregon.

McCune B. and Mefford M.J., 1999. PC-ORD, Multivariate Analysis of Ecological Data Version 4.25, MjM Software Design, Gleneden Beach.

Merritt R.W. and Cummins K.W., 1996. An Introduction to the Aquatic Insects of North America, Kendall/Hunt Publishing Company, Dubuque.
Ministry of Environmental Protection, China, 2002. Environmental Quality Standard for Surface Water, GB3838-2002, http://english.mep.gov.cn/.

Nelson S.M. and Roline R.A., 1996. Recovery of a stream macroinvertebrate community from mine drainage disturbance. Hydrobiologia, 339, 73-84.

Paule A., Lyautey E., Garabetian F. and Rols J.L., 2009. Autogenic versus environmental control during development of river biofilm. Ann. Limnol. - Int. J. Lim., 45, $1-10$.

Peterson W.T. and Keister J.E., 2003. Interannual variability in copepod community composition at a coastal station in the northern California Current: a multivariate approach. DeepSea Res., 50, 2499-2517.

Pielou E.C., 1966. Shannon's formulae as a measure of specific diversity: its use and misuse. Am. Nat., 100, 463-465.

Shannon C.E., 1948. A mathematical theory of communication. Bell System Technical Journal, 27, 379-423, 623-656.

Solà C. and Prat N., 2006. Monitoring metal and metalloid bioaccumulation in Hydropsyche (Trichoptera Hydropsychidae) to evaluate metal pollution in a mining river. Whole body versus tissue content. Sci. Total Environ., 359, 221-231.

Specht W.L., Cherry D.S., Lechleitner R.A. and Cairns J., 1984. Structural functional and recovery responses of stream invertebrates to fly ash effluent. Can. J. Fish. Aquat. Sci., 41, 884-896.

StatSoft, Inc., 2004. STATISTICA (data analysis software system), version 7, www.statsoft.com.

United Nation Educational, Scientific and Cultural Organization (UNESCO), 2003. Three Parallel Rivers of Yunnan Protected areas, http://whc.unesco.org/en/list/ 1083.

van Damme P.A., Hamel C., Ayala A. and Bervoets L., 2008. Macroinvertebrate community response to acid mine drainage in rivers of the High Andes (Bolivia). Environ. Pollut., 156, 1061-1068.

Vannote R.L., Minshall G.W., Cummins K.W., Sedell J.R. and Cushing C.E., 1980. The river continuum concept. Can. J. Fish. Aquat. Sci., 37, 130-137.

Ward J.V., 1994. Ecology of alpine streams. Freshwat. Biol., 32, 277-294.

Watanabe K., Monaghan M.T., Takemon Y. and Omura T., 2008. Biodilution of heavy metals in a stream macroinvertebrate food web: Evidence from stable isotope analysis. Sci. Total Environ., 394, 57-67.

Weatherley A.H., Lake P.S. and Rogers S.C., 1980. Zinc pollution and the ecology of the freshwater environment. In: Nriagu J.O. (ed.), Zinc in the Environment. Part I. Ecological Cycling, Wiley-Interscience, New York, 337-418.

Weigel B.M., Henne L.J. and Martínez-Rivera L.M., 2002. Macroinvertebrate-based index of biotic integrity for protection of streams in west-central Mexico. J. N. Am. Benthol. Soc., 21, 686-700.

Wu N.C., Tang T., Qu X.D. and Cai Q.H., 2007. Spatial distribution of benthic algae in the Gangqu River, Shangrila, China. Aquat. Ecol., 43, 37-49.

Zimmerman G.M., Goetz H. and Mielke P.W., 1985. Use of an improved statistical method for group comparisons to study effects of prairie fire. Ecology, 66, 606-611. 